\title{
PENGARUH SUPERVISI KEPALA SEKOLAH DAN KOMUNIKASI ANTAR PRIBADI TERHADAP KEPUASAN KERJA GURU SD NEGERI SE- KECAMATAN LIMA KAUM
}

\author{
Rian Yohanas \\ Staf Kantor Wali Nagari Cubadak, \\ Korespondensi: Jorong Supanjang Nagari Cubadak Kecamatan Lima Kaum \\ Kabupaten Tanah Datar \\ e-mail: rianyohanas@gmail.com
}

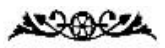

\begin{abstract}
This study aims to determine: (1) principal supervision of teacher work satisfaction; (2) interpersonal communication of teacher work satisfaction; and (3) principal supervision and interpersonal communication of teacher work satisfaction. This research is expost facto that is research which aims to know influence of a variable to other variables. The population of this research is Elementary school teachers in Lima Kaum District as many as 153 people. The sampling using probability sampling technique, so the sample amounted to 60 people. The data collection is questionnaires and documentation. Testing the instrument with validity and reliability test. Data analysis techniques use descriptive statistics and inferential statistics with prerequisite analysis test using normality test, homogeneity test, linearity test, multicollinearity test and autocorrelation test. The bypothesis test using partial test (t test) and simultaneous test (F test). The results are: (1) principal supervision did not affect of teacher job satisfaction; (2) interpersonal communication influenced of teacher work satisfaction; and (3) principal supervision and interpersonal communication (X2) together towards teacher work satisfaction. If the principal supervision is done well and interpersonal communication is done effectively will have a positive effect on the improvement of teacher work satisfaction.
\end{abstract}

Keywords: Principal Supervision, Communication, Work Satisfaction.

\section{PENDAHULUAN}

Manusia merupakan makhluk sosial yang salah satu kegiatannya adalah bekerja, sehingga manusia cenderung untuk bekerja dan menyukai pekerjaannya. Kerja adalah kegiatan melakukan sesuatu yang dilakukan atau diperbuat, seperti guru yang bekerja untuk mengajar murid-muridnya.

Guru adalah seorang tenaga pendidik professional. UU nomor 14 tahun 2005 tentang guru dan dosen secara tersirat menyebutkan bahwa seorang guru adalah pendidik profesional dengan tugas utama mendidik, mengajar, membimbing, mengarahkan, melatih, menilai, dan mengevaluasi peserta didik. Namun ironisnya kondisi guru saat ini bersumber dari pola-pola bangsa ini memperlakukannya. Meskipun diakui guru sebagai unsur penting dalam pembangunan bangsa, akan tetapi guru belum memperoleh penghargaan yang wajar sesuai dengan martabat serta hak azazinya. Hal itu tercermin belum adanya jaminan kepastian dan 
perlindungan bagi para guru dalam pelaksanaan tugas dan perolehan hak-haknya sebagai pribadi, tenaga kependidikan, dan warga Negara (Fattah, 2000: 5).

Keberhasilan pendidikan tidak terlepas dari peran dan tugas guru sebagai pelaksana pendidikan. Seorang guru harus mampu memanfaatkan segala sumber daya pendidikan yang ada dalam upaya pencapaian tujuan pendidikan. Sebagai pelaksana pendidikan, seorang guru harus memiliki kemampuan teknis terkait dengan penggunaan segala sumber daya pendidikan yang ada dalam kegiatan belajar mengajar di kelas. Tinggi rendahnya mutu pendidikan sesungguhnya merupakan tanggung jawab segenap bangsa, akan tetapi pandangan masyarakat menunjukkan bahwa rendahnya mutu pendidikan senantiasa diasumsikan dengan rendahnya kinerja guru, rendahnya komunikasi antar pribadi, rendahnya mutu kepala sekolah, kurang profesionalnya guru, dan kurangnya disiplin guru. Untuk mengetahui gambaran peningkatan profesionalisme guru adalah dengan melihat tercapainya kepuasan kerja guru yang ditandai dengan optimalisasi kerja para guru, guru merasa bergairah, dan guru merasa bahagia dalam menjalankan tugas dan tanggung jawab yang diembannya.

Puas adalah merasa senang, lega, gembira, kenyang, dan sebagainya, karena sudah terpenuhi hasrat hatinya. Kepuasan pada dasarnya muncul karena adanya kebutuhan yang terpenuhi dan dirasakan oleh individu baik kebutuhan primer, sekunder dan tersier. Namun, yang perlu diperhatikan adalah pemenuhan kebutuhan tersebut tidak selalu bermula dari kebutuhan pokok/dasar, akan tetapi bergeser sesuai dengan kebutuhan dan presentase pengembangan diri individu. Guru dalam bekerja tidak semata-mata hanya mengejar kebutuhan ekonomi, akan tetapi kebutuhan aktualisasi diri yang merupakan salah satu kebutuhan yang mendorong rasa puas dan senang dalam melaksanakan tugas.

Menurut Hasibuan (2007: 202), kepuasan kerja adalah sikap emosional yang menyenangkan dan mencintai pekerjaannya. Sikap ini dicerminkan oleh moral kerja, kedisiplinan, dan prestasi kerja. Kepuasan kerja dinikmati dalam pekerjaan, luar pekerjaan, dan kombinasi dalam dan luar pekerjaan.

Robbins dan Judge (Virgana, 2014: 12) menyatakan bahwa kepuasan kerja merupakan perasaan positif tentang pekerjaan seseorang yang dihasilkan oleh evaluasi tentang karakteristik pekerjaannya (job satisfaction is a positive feeling about one's job resulting from an evaluation of its characteristics). Perasaan positif yang dimaksud adalah adanya perasaan senang, bangga, lega, dan perasaan lain yang mengungkapkan adanya kesesuaian antara harapan dengan kenyataan dalam kaitan dengan pekerjaan yang telah dilakukan. Menurut Siagian (2006: 295), kepuasan kerja merupakan suatu cara pandang baik positif maupun negatif tentang pekerjaannya. Individu yang mempunyai kepuasan kerja yang tinggi akan mempunyai sikap yang positif terhadap pekerjaan yang dilakukannya, sedangkan individu yang tidak puas hati dengan pekerjaannya mempunyai sikap yang sebaliknya.

Menciptakan kepuasan kerja guru yang optimal tentu bukan pekerjaan yang mudah, karena kepuasan kerja dipengaruhi oleh banyak faktor. Menurut Gilmer dalam Sutrisno (2011: 77-78), faktor yang mempengaruhi kepuasan kerja yaitu: (1) kesempatan untuk maju, (2) keamanan 
kerja, (3) gaji, (4) perusahaan dan manajemen, (5) supervisi, (6) kondisi kerja (7) aspek sosial dalam pekerjaan, (8) komunikasi, dan (9) fasilitas.

Sedangkan Herzberg dalam Munir (2013: 25-26) menyebutkan terdapat beberapa faktor yang mempengaruhi kepuasan kerja dan tidak kepuasan kerja. Faktor tersebut dibedakan menjadi dua golongan sehingga teori ini disebut teori dua faktor. Faktor pertama disebut motivator atau pembawa kepuasan, yaitu (1) prestasi, (2) pengakuan, (3) pekerjaan itu sendiri, (4) tanggung jawab, dan (5) promosi. Faktor kedua adalah faktor yang menyebabkan ketidakpuasan meliputi; (1) hubungan interpersonal dengan bawahan, (2) hubungan interpersonal dengan atasan, (3) hubungan interpersonal dengan rekan kerja, (4) supervisi, (5) kebijakan dan administrasi, (6) kondisi kerja, dan (7) kehidupan pribadi.

Dalam melaksanakan tugasnya, guru tidak terlepas dari kepemimpinan seorang kepala sekolah. Dalam hal ini, seorang pemimpin lembaga pendidikan/sekolah adalah kepala sekolah. Kepala sekolah merupakan salah satu komponen pendidikan yang paling berperan dalam meningkatkan kualitas pendidikan. Dalam Peraturan Pemerintah Nomor 28 tahun 1990 pasal 12 ayat 1 dijelaskan bahwa "kepala sekolah bertanggung jawab atas penyelenggaraan kegiatan pendidikan, administrasi sekolah, pembina tenaga kependidikan lainnya dan pendayagunaan serta pemeliharaan sarana dan prasarana."

Selain itu mengingat peran guru yang besar dalam proses pendidikan, kepala sekolah sebagai atasan langsung dituntut memiliki kapasitas utama sebagai edukator, manajer, administrator, supervisor, leader, inovator, dan motivator (Samana, 1994).

Kepala sekolah sebagai supervisor bertugas memberikan bantuan dan bimbingan secara profesional kepada guru yang kurang memiliki kemampuan profesional dalam mengajar. Hal ini sesuai dengan hakikat supervisi yang merupakan usaha memberi pelayanan agar guru menjadi lebih profesional dalam menjalankan tugas melayani peserta didiknya. Pelayanan profesional kepala sekolah terhadap guruguru sangat esensial bagi peningkatan kualitas proses belajar-mengajar (PBM). Dengan demikian dapat dikatakan bahwa supervisi yang dilakukan kepala sekolah merupakan usaha untuk membantu para guru meningkatkan kualitas pembelajaran. Mengingat baiknya tujuan ini, maka seyogyanya semua yang dilakukan oleh kepala sekolah hendaknya dilandasi dengan niat yang tulus dan ikhlas. Dengan adanya supervisi baik, tentu para guru akan merasa terbantu dalam menyelesaikan setiap permasalahan yang dihadapi.

Sebagai supervisor, kepala sekolah juga diharapkan mampu bertindak sebagai konsultan, sebagai fasilitator yang memahami kebutuhan dari guru dan juga mampu memberi alternatif pemecahannya. Selain itu kepala sekolah juga diharap dapat memotivasi guru-guru agar lebih kreatif dan inovatif. Dalam kerangka pembinaan kompetensi guru melalui supervisi perlu dicermati bahwa kegiatan tersebut bukan hanya memfokuskan pada peningkatan pengetahuan dan ketrampilan mengelola pembelajaran, tetapi juga mendorong semangat guru dalam bekerja sehingga dapat meningkatkan kepuasan guru dalam bekerja. 
Selain supervisi kepala sekolah, komunikasi juga salah satu penentu kepuasan kerja bagi guru, karena komunikasi merupakan salah satu faktor yang amat penting dalam menjalankan proses administrasi dan interaksi antar elemen pada suatu organisasi/lembaga, baik internal maupun eksternal. Tanpa adanya jalinan komunikasi yang baik dan benar, besar kemungkinan semua proses di organisasi/lembaga tersebut tidak akan dapat berjalan maksimal sesuai dengan yang telah direncanakan.

Menurut Weihrich dan Koontz dalam Munir (2013: 38), mendefenisikan komunikasi sebagai pemindahan/pengiriman suatu informasi dari seorang pengirim kepada seorang penerima, dengan catatan bahwa informasi tersebut bisa dimengerti dan dipahami oleh sang penerima.

Menurut Suranto (2011: 10), perkantoran yang berfungsi baik ditandai oleh adanya kerjasama secara sinergis dan harmonis dari berbagai komponen. Senantiasa terjadi komunikasi, kerjasama, saling koreksi dan terdapat sistem pembagian tugas antar komponen tersebut. Suatu perkantoran dikonstruksi dan dipelihara dengan komunikasi. Artinya, ketika proses komunikasi antar komponen tersebut dapat diselenggarakan secara harmonis, maka perkantoran tersebut semakin kokoh dan kepuasan kerja setiap komponen akan terwujud.

Dari pendapat para ahli di atas dapat dipahami bahwa komunikasi merupakan kebutuhan hakiki dalam kehidupan manusia untuk saling tukar menukar informasi. Karena tanpa komunikasi dan interaksi antar manusia, baik secara perorangan, kelompok maupun organisasi tidak mungkin terjadi. Manusia memerlukan kehidupan sosial, kehidupan bermasyarakat. Sebagian besar interaksi manusia berlangsung dalam situasi komunikasi interpersonal (komunikasi antar pribadi).

Kepala sekolah sebagai pemimpin pendidikan harus mempunyai bekal komunikasi yang baik, karena akan dapat membantu keberhasilan pemimpin dalam menjalankan tugasnya sebagai penentu kebijakan. Seorang yang mampu berkomunikasi dengan baik akan dapat membaca perasaan orang lain yang sedang diajak berkomunikasi dan akan mampu menciptakan kepuasan dalam berkomunikasi.

Proses komunikasi yang terjadi di dalam organisasi khususnya yang menyangkut komunikasi antara pimpinan dan bawahan merupakan faktor penting dalam menciptakan suatu organisasi yang efektif. Komunikasi yang efektif tergantung dari hubungan karyawan yang memuaskan yang dibangun berdasarkan kepercayaan atau suasana organisasi yang positif. Hubungan atasan dan bawahan merupakan jantung pengelolaan yang efektif. Agar hubungan ini berhasil, harus ada kepercayaan dan keterbukaan antara atasan dan bawahan. (Abdulkadir, 2001: 172).

Bertitik tolak dari pendapat di atas, dapat penulis simpulkan bahwa masalah supervisi kepala sekolah dan komunikasi antar pribadi dalam meningkatkan kepuasan kerja guru merupakan salah satu faktor yang harus di perhatikan. Untuk mengungkapkan keadaan yang sebenarnya maka penulis tertarik dan merasa perlu untuk meneliti, "Pengaruh Supervisi Kepala Sekolah dan Komunikasi Antar Pribadi Terhadap Kepuasan Kerja Guru SD Negeri SeKecamatan Lima Kaum". 


\section{KAJ IAN TEORI}

\section{Kepuasan Kerja}

Kepuasan kerja erat kaitnnya dengan perasaan seseorang. Menurut Hasibuan (2007: 202), kepuasan kerja adalah sikap emosional yang menyenangkan dan mencintai pekerjaannya. Sikap ini dicerminkan oleh moral kerja, kedisiplinan, dan prestasi kerja. Kepuasan kerja dinikmati dalam pekerjaan, luar pekerjaan, dan kombinasi dalam dan luar pekerjaan. Kepuasan kerja dalam pekerjaan merupakan kepuasan kerja yang dinikmati dalam pekerjaan dengan memperoleh pujian hasil kerja, penempatan, perlakuan, peralatan dan suasana lingkungan kerja yang baik. Kepuasan di luar pekerjaan adalah kepuasan kerja yang dinikmati di luar pekerjaan dengan besarnya balas jasa yang diterima dapat memenuhi kebutuhan hidup. Sedangkan kepuasan dalam dan luar pekerjaan dicerminkan melalui kombinasi balas jasa dengan pelaksanaan pekerjaan.

Menurut Sutrisno (2011: 74), pertama kepuasan kerja adalah suatu reaksi emosional yang kompleks akibat dari dorongan, keinginan, tuntutan dan harapan karyawan sehingga timbul perasaan senang, puas ataupun tidak puas. Kedua, kepuasan kerja adalah suatu sikap karyawan terhadap pekerjaan yang berhubungan dengan situasi kerja, kerja sama antar karyawan, imbalan yang diterima dalam kerja dan hal-hal yang menyangkut faktor fisik dan psikologis. Seseorang yang tingkat kepuasan kerjanya tinggi menunjukkan sikap positif terhadap kerja. Tiffin dalam (Sutrisno, 2011: 7) menyatakan kepuasan kerja berkaitan dengan sikap dari karyawan terhadap pekerjaannya sendiri, situasi kerja, kerjasama antar pimpinan dengan sesama karyawan.
Handoko dalam (Sutrisno, 2011: 75), menyatakan bahwa kepuasan kerja adalah keadaan emosional yang menyenangkan atau tidak menyenangkan bagi para karyawan memandang pekerjaan mereka. Kepuasan kerja mencerminkan perasaan seseorang terhadap pekerjaannya yang ditunjukkan melalui sikap positif karyawan terhadap pekerjaan dan segala sesuatu yang dihadapi di lingkungan pekerjaannya. Seseorang yang dapat relatif puas dengan suatu aspek dari pekerjaannya dan tidak puas dengan salah satu atau lebih aspek yang lainya. Aspek itu meliputi: pekerjaan, upah, promosi, rekan kerja, pengawasan, pengakuan, kompensasi, dan lain-lain.

Berdasarkan beberapa pengertian di atas, maka dapat ditarik kesimpulan bahwa kepuasan kerja merupakan suatu perilaku yang didasarkan pada psikologis seseorang berhubungan dengan senang-tidaknya pada pekerjaan yang dijalaninya dalam mencapai tujuan organisasi, antara yang diharapkan atau tidak sesuai dengan keinginan.

\section{Faktor yang mempengaruhi kepuasan kerja}

a. Supervisi Kepala Sekolah

Supervisi secara etimologi berasal dari kata "super" dan "visi" yang mengandung arti melihat dan meninjau dari atas atau menilik dan menilai dari atas yang dilakukan oleh pihak atasan terhadap aktivitas, kreativitas, dan kinerja bawahan (Mulyasa, 2012: 239).

Menurut Purwanto (1998: 76) supervisi adalah suatu aktivitas pembinaan yang direncanakan untuk membantu para guru dan pegawai sekolah lainnya dalam melakukan pekerjaan secara efektif. Sedangkan Sahertian (2000: 19) mendefinisikan supervisi sebagai usaha memberikan pelayanan dan bantuan 
kepada guru-guru baik secara individual maupun secara kelompok dalam usaha memperbaiki pengajaran.

Dalam pengertian lain, supervisi adalah suatu aktivitas pembinaan yang direncanakan untuk membantu para guru dan pegawai sekolah dalam melakukan pekerjaan mereka secara efektif. Dengan demikian hakekat supervisi adalah suatu proses bimbingan dari pihak kepala sekolah kepada guru-guru dan personalia sekolah yang langsung menangani belajar para siswa, disamping itu juga memperbaiki situasi bekerja dan belajar secara efektif, disiplin, bertanggung jawab, dan memenuhi akuntabilitas (Suprihatiningrum, 2013: 289). Kata kunci dari pelaksanaan supervisi adalah "memberi layanan dan bantuan".

Sesuai dengan standar kompetensi kepala sekolah menurut Permendiknas Nomor 13 Tahun 2007, bahwa kepala sekolah sebagai supervisor, harus memiliki kompetensi supervisi, diantaranya:

1) Merencanakan program supervisi dalam rangka peningkatan profesionalisme guru, diantaranya: Program Perencanaan Supervisi, pengadaan buku catatan, instrumen, dan jadwal supervisi pembelajaran.

2) Melaksanakan supervisi terhadap guru dengan menggunakan pendekatan dan teknik supervisi yang tepat, diantaranya : supervisi terhadap kemampuan guruguru dalam merecanakan kegiatan pembelajaran, melaksanakan kegiatan pembelajaran, menilai hasil pembelajaran, memanfaatkan hasil penilaian untuk peningkatan layanan pembelajaran, menciptakan lingkungan belajar yang menyenangkan, memanfaatkan sumber belajar yang tersedia, dan mengembangkan interaksi pembelajaran (strategi, metode, dan teknik) yang tepat.

3) Menindaklanjuti hasil supervisi terhadap guru dalam rangka peningkatan profesionalisme guru, di antaranya: penguatan dan penghargaan diberikan kepada guru yang telah memenuhi standar; teguran dan hukuman yang bersifat mendidik diberikan kepada guru yang belum memenuhi standar; dan guru diberi kesempatan untuk mengikuti pelatihan/penataran, lokakarya, seminar, studi lebih lanjut (Lantip dan Sudiyono, 2011: 95).

Kepala sekolah selaku manajer sekolah dan supervisor berperan penting dalam mewujudkan sistem manajemen sekolah yang unggul dan efektif. Sebagai supervisor, kepala sekolah mempunyai peran penting, di antaranya:

1) Mengadakan observasi di setiap kelas untuk peningkatan efektifitas proses pembelajaran.

2) Melaksanakan pertemuan individual dengan guru untuk menggali potensi masing-masing guru.

3) Menyediakan waktu dan pelayanan bagi guru dalam upaya pemecahan masalah akademik dan administrasi.

4) Menyediakan dukungan dan suasana kondusif bagi guru dalam perbaikan dan peningkatan kinerja guru.

5) Melaksanakan pengembangan staf secara terencana, terarah, dan berkelanjutan.

6) Bekerja sama dengan guru untuk mengevaluasi hasil belajar secara komprehensif.

7) Melaksanakan penelitian sederhana untuk perbaikan situasi dan kondisi proses pembelajaran (Suprihatiningrum, 2013: 299). 
b. Komunikasi antar pribadi

Secara etimologis, istilah komunikasi berasal dari bahasa Latin communicatio, dan perkataan ini bersumber pada kata communis. Arti communis disini adalah sama, dalam arti kata sama makna (Effendy, 2008: 3). Maksudnya sama makna disini adalah persamaan persepsi terhadap suatu hal yang diupayakan oleh pihak yang menyampaikan pesan terhadap pihak yang menerima pesan. Karena komunikasi dapat berjalan baik apabila antara pihak yang terlibat proses komunikasi terdapat kesamaan makna dalam mengartikan apa yang dikomunikasikan.

Kemudian jika kita berbicara mengenai komunikasi antar pribadi atau komunikasi interpersonal pada dasarnya memiliki pengertian sebagaimana komunikasi secara umumnya. Dalam proses komunikasi antar pribadi juga terdapat komunikator, pesan dan komunikan. Hanya saja komunikasi antar pribadi merujuk pada komunikasi yang terjadi secara langsung antara dua orang atau lebih.

Arni (2011: 159) berpendapat bahwa komunikasi antar pribadi adalah proses pertukaran informasi diantara seseorang dengan paling kurang seorang lainnya atau biasanya diantara dua orang yang dapat langsung diketahui balikannya.

Dari beberapa pengertian di atas menjelaskan bahwa komunikasi antar pribadi atau yang pada saat ini dikenal dengan komunikasi interpersonal merupakan proses komunikasi yang dilakukan oleh seseorang dengan satu orang lainnya atau lebih secara langsung. Karena komunikasi bentuk ini dilakukan secara langsung maka feedback dari seorang komunikan terhadap informasi yang disampaikan dapat langsung diketahui. Menurut Gilmer (Sutrisno, 2011:
78) Komunikasi yang lancar antarkaryawan dengan pihak manajemen banyak dipakai alasan untuk menyenangi jabatannya. Dalam hal ini adanya kesediaan pihak atasan untuk mau mendengar, memahami, dan mengakui pendapat ataupun prestasi karyawannya sangat berperan dalam menimbulkan rasa puas akan berkerja.

\section{METODE PENELTIAN}

Penelitian ini menggunakan pendekatan kuantitatif dengan jenis penelitian expost facto. Menurut Subana dan Sudrajat (2005: 25-37), penelitian kuantitatif biasanya dipakai untuk menguji suatu teori, untuk menyajikan suatu fakta atau mendeskripsikan statistik, dan ada pula yang bersifat mengembangkan konsep, pemahaman, atau mendeskripsikan banyak hal. Selanjutnya, penelitian ini digunakan untuk mengetahui pengaruh antara variabel yang satu dengan variabel yang lain dengan menggunakan koefisien korelasi, menentukan signifikan atau tidak signifikan, serta menunjukkan arah positif atau negatif pada hubungan antar variabel tersebut.

Penelitian ini melihat pengaruh antara supervisi kepala sekolah $\left(\mathrm{X}_{1}\right)$ dengan kepuasan kerja guru (Y) dan pengaruh antara komunikasi antar pribadi $\left(\mathrm{X}_{2}\right)$ terhadap kepuasan kerja guru (Y) di SD Negeri se-Kecamatan Lima kaum Kabupaten Tanah Datar.

\section{HASIL PENELTIAN DAN PEMBAHASAN}

\section{Hasil Penelitian}

Hasil penelitian dari 60 orang responden menjelaskan bahwa kepuasan kerja guru di SD Negeri Se-Kecamatan 
Lima Kaum dalam kategori sangat puas sebanyak 10 orang (16,70\%), puas sebanyak 44 orang $(73,30 \%)$, cukup puas sebanyak 10 orang $(6,00 \%)$, kurang puas 0 orang $(0,00 \%)$, dan tidak puas sebanyak 0 orang $(0,00 \%)$.

\section{Gambar 1}

\section{Grafik Kategori Kepuasan Kerja Guru}

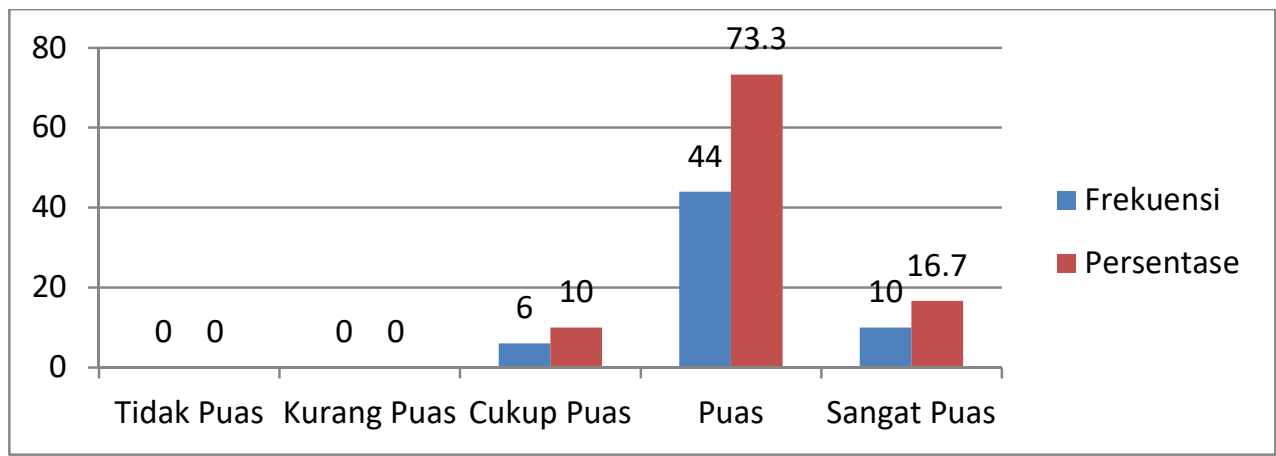

Untuk menciptakan pendidikan yang berkualitas, kepuasan kerja guru perlu diperhatikan. Guru yang memiliki kepuasan kerja yang baik akan mendarmabaktikan keahlian, ilmu, dan segala upayanya untuk mendidik dengan baik. Oleh karena itu untuk menciptakan kepuasan kerja guru tersebut perlu diperhatikan faktor-faktor yang dapat mempengaruhinya. Dari hasil analisis regresi diperolehnya harga $\mathrm{F}_{\text {hitung }}=$ 4,192 > F tabel 3,16 dan harga $\mathrm{p}$ sebesar 0,020 . Nilai $p$ jauh lebih kecil dari taraf signifikansi $(\alpha)=0,05$. Berdasarkan pengujian ini dapat disimpulkan bahwa:

a. Terdapat pengaruh positif dari supervisi kepala sekolah dan komunikasi antar pribadi terhadap kepuasan kerja guru. Artinya semakin baik supervisi kepala sekolah dan semakin efektif komunikasi antar pribadi secara bersama-sama akan meningkatkan kepuasan kerja guru dan sebaliknya, semakin tidak baik supervisi kepala sekolah dan tidak efektif komunikasi antar pribadi secara bersama-ama akan mengakibatkan rendahnya kepuasan kerja guru.

b. Besarnya proporsi pengaruh supervisi kepala sekolah dan komunikasi antar pribadi terhadap kepuasan kerja guru berdasarkan uji koefisien determinasi $(\Delta \mathrm{R} 2)$ sebesar 0,128 yang artinya variabel supervisi kepala sekolah dan komunikasi antar pribadi secara bersama-sama hanya memberikan pengaruh sebesar 9,8\% terhadap kepuasan kerja guru, sedangkan sisanya 90,2\% dipengaruhi oleh variabel lain di luar model regresi linier ini.

Secara deskriptif penelitian ini berhasil mengungkap dari 60 orang guru SD Negeri Se-Kecamatan Lima Kaum yang menjadi responden, diketahui bahwa supervisi kepala sekolah di SD Negeri SeKecamatan Lima Kaum dalam kategori sangat baik sebanyak 23 orang (38,30\%), baik sebanyak 30 orang $(50,00 \%)$, cukup baik sebanyak 7 orang (11,70\%), kurang baik 0 orang $(0,00 \%)$, dan tidak baik sebanyak 0 orang $(0,00 \%)$. 


\section{Gambar 2}

\section{Grafik Kategori Supervisi Kepala Sekolah}

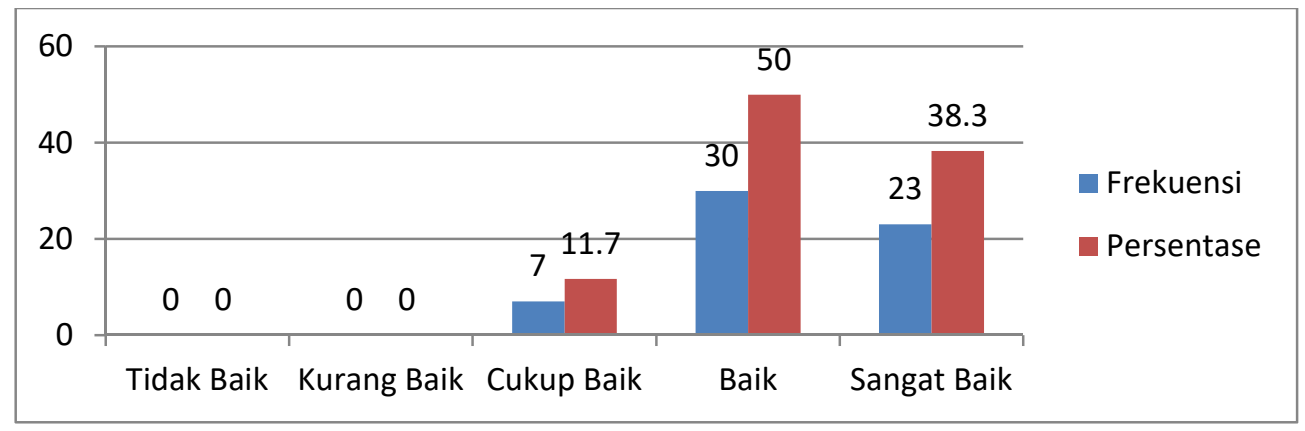

Dari hasil penguiian hipotesis diperoleh harga $t_{\text {hitung }}=1,019<\mathrm{t}_{\text {tabel }} 2,000$ dan harga $p$ sebesar 0,312 . Nilai p jauh lebih besar dari taraf signifikansi $(\alpha)=0,05$ yang digunakan. Hasil ini menunjukkan bahwa tidak terdapat pengaruh antara supervisi kepala sekolah terhadap kepuasan kerja guru di SD Negeri se-Kecamatan Lima Kaum. Dengan demikian dapat dikatakan bahwa baik atau tidaknya supervisi yang dilakukan kepala sekolah tidak akan berpengaruh terhadap kepuasan guru dalam bekerja.
Temuan lain dalam penelitian ini berhasil mengungkap dari 60 orang guru SD Negeri Se-Kecamatan Lima Kaum yang menjadi responden, diketahui bahwa komunikasi antar pribadi di SD Negeri SeKecamatan Lima Kaum dalam kategori sangat efektif sebanyak 8 orang $(13,30 \%)$, efektif sebanyak 48 orang $(80,00 \%)$, cukup efektif sebanyak 4 orang $(6,70 \%)$, kurang efektif 0 orang $(0,00 \%)$, dan tidak efektif sebanyak 0 orang $(0,00 \%)$.

Gambar 3

Grafik Kategori Komunikasi Antar Pribadi

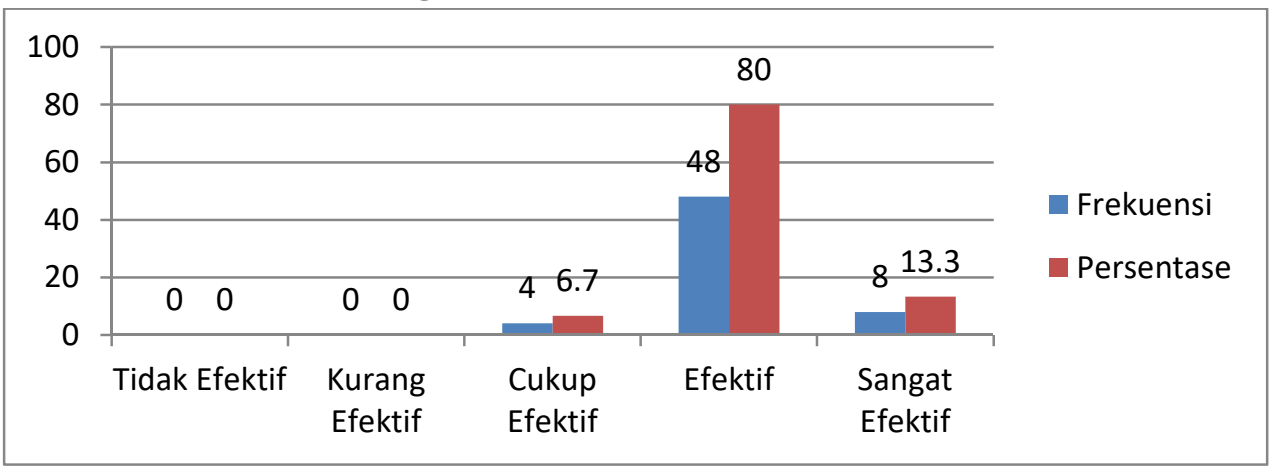

Dari hasil pengujian hipotesis diperoleh harga $\mathrm{t}_{\text {hitung }}=2,699>\mathrm{t}_{\text {tabel }} 2,000$ dan harga p sebesar 0,009 . Nilai p jauh lebih kecil dari taraf signifikansi $(\alpha)=0,05$ yang digunakan. Hasil ini menunjukkan bahwa terdapat pengaruh antara komunikasi antar pribadi terhadap kepuasan kerja guru di SD Negeri se-Kecamatan Lima Kaum. Dengan demikian dapat dikatakan bahwa semakin efektif komunikasi antar pribadi maka semakin tinggi kepuasan guru dalam bekerja. 
Dengan menggunakan uji koefisien determinasi diperoleh nilai Adjusted $\mathrm{R}$ Square yang besarnya 0,097. Hal ini menunjukkan bahwa sumbangan atau proporsi pengaruh variabel komunikasi antar pribadi terhadap kepuasan kerja guru sebesar 9,7\%. Artinya komunikasi antar pribadi memiliki proporsi pengaruh terhadap kepuasan kerja guru sebesar 9,7\% sedangkan sisanya 90,3\% dipengaruhi oleh variabel lain yang tidak ada dalam model regresi linier ini.

\section{Pembahasan}

Berdasarkan hasil penelitian yang telah diuraikan, berikut ini dipaparkan pembahasan atas jawaban dari hipotesis penelitian.

a. Pengaruh Supervisi Kepala Sekolah Terhadap Kepuasan Kerja Guru SD Negeri Se-Kecamatan Lima Kaum

Hasil penelitian menunjukkan bahwa supervisi kepala sekolah tidak berpengaruh terhadap kepuasan kerja guru. Hal tersebut tidak sesuai dengan teori yang diungkapkan oleh Gilmer dalam (Sutrisno, 2011: 77-78) bahwa salah satu faktor yang mempengaruhi kepuasan kerja guru adalah pengawasan (supervisi), kemudian penelitian ini sesuai dengan hasil penelitian yang dilakukan oleh I Made Angga Wiguna dan Dharma Suputra (2016: 464), Universitas Udayana Bali, yang berjudul "Pengaruh Tindakan Supervisi, Pengalaman Kerja, Komitmen Organisasi, dan Komitmen Profesional Terhadap Kepuasan Kerja Auditor". menyatakan bahwa tindakan supervisi tidak berpengaruh secara parsial terhadap kepuasan kerja auditor di kantor akuntan publik Denpasar. Dari hasil penelitian dapat dijelaskan bahwa supervisi kepala sekolah tidak termasuk ke dalam faktor yang mempengaruhi kepuasan guru. Berarti kepuasan kerja guru di SD Negeri Se-Kecamatan Lima Kaum lebih dipengaruhi faktor lain diluar dari model regresi ini.

b. Pengaruh Komunikasi Antar Pribadi Terhadap Kepuasan Kerja Guru SD Negeri Se-Kecamatan Lima Kaum Hasil penelitian menunjukkan bahwa komunikasi antar pribadi berpengaruh terhadap kepuasan kerja guru, artinya semakin baik komunikasi antar pribadi akan meningkatkan kepuasan kerja guru dan sebaliknya, semakin tidak baik komunikasi antar pribadi akan mengakibatkan rendahnya kepuasan kerja guru. Hal tersebut sesuai dengan teori yang diungkapkan Gilmer dalam (Sutrisno, 2011: 77-78) bahwa salah satu faktor yang mempengaruhi kepuasan kerja guru adalah komunikasi. Dari hasil penelitian dapat dijelaskan bahwa komunikasi antar pribadi termasuk salah satu faktor yang mempengaruhi kepuasan kerja guru. Berarti kepuasan kerja guru di SD Negeri Se-Kecamatan Lima Kaum salah satunya dipengaruhi oleh komunikasi antar pribadi.

c. Pengaruh Supervisi Kepala Sekolah dan Komunikasi Antar Pribadi Terhadap Kepuasan Kerja Guru SD Negeri SeKecamatan Lima Kaum

Hasil penelitian ini menunjukkan bahwa supervisi kepala sekolah dan komunikasi antar pribadi secara simultan (bersamasama) berpengaruh terhadap kepuasan kerja guru, artinya semakin baik supervisi kepala sekolah dan komunikasi antar pribadi secara bersama-sama akan meningkatkan kepuasan kerja guru dan sebaliknya, semakin tidak baik supervisi 
kepala sekolah dan komunikasi antar pribadi secara bersama-ama akan mengakibatkan rendahnya kepuasan kerja guru.

\section{PENUTUP}

\section{Kesimpulan}

Berdasarkan hasil penelitian dan analisis yang telah dilakukan maka dapat disimpulkan bahwa: (1) tidak terdapat pengaruh antara supervisi kepala sekolah terhadap kepuasan kerja guru di SD Negeri Se-Kecamatan Lima Kaum, dikarenakan nilai $\mathrm{t}$ hitung 1,019 < tabel 2,000, artinya baik atau tidak supervisi kepala sekolah tidak akan berpengaruh terhadap kepuasan kerja guru. (2) terdapat pengaruh antara komunikasi antar pribadi terhadap kepuasan kerja guru di SD Negeri Se-Kecamatan Lima Kaum, dikarenakan nilai $\mathrm{t}$ hitung 2,699 > t tabel 2,000, artinya semakin efektif komunikasi antar pribadi akan meningkatkan kepuasan kerja guru dan sebaliknya, semakin tidak efektif komunikasi antar pribadi akan mengakibatkan rendahnya kepuasan kerja guru. (3) terdapat pengaruh supervisi kepala sekolah dan komunikasi antar pribadi secara simultan (bersama-sama) terhadap kepuasan kerja guru di SD Negeri Se-Kecamatan Lima Kaum, dikarenakan nilai $\mathrm{F}$ hitung 4,192 > F tabel 3,160, artinya semakin baik supervisi kepala sekolah dan efektif komunikasi antar pribadi secara bersama-sama akan meningkatkan kepuasan kerja guru dan sebaliknya, semakin tidak baik supervisi kepala sekolah dan tidak efektif komunikasi antar pribadi secara bersama-sama akan mengakibatkan rendahnya kepuasan kerja guru.

\section{Saran}

a. Supervisi tidak boleh diabaikan oleh kepala sekolah karena merupakan salah satu fungsi dari seorang kepala sekolah, untuk itu perlu meningkatkan pelaksanaannya secara baik.

b. Sebagai seorang guru tentunya merupakan contoh dan tauladan bagi siswanya. Untuk itu dalam berkomunikasi antar pribadi hendaknya diciptakan secara efektif agar meningkatkan kepuasan dalam bekerja.

c. Kepuasan guru dalam bekerja akan terlihat dari keiklasan guru dalam mengajar untuk itu disarankan kepada guru untuk membuat suasana yang nyaman dalam bekerja.

\section{KEPUSTAKAAN ACUAN}

Abdulkadir, M. (2001), Etika Profesi Hukum, CV Citra Aditya Bakti, Jakarta.

Arni, M. (2011). Komunikasi Organisasi. Jakarta: Bumi Aksara, Ed. 1, Cet. 12.

Effendy, Onong Uchjana. (2008). Dinamika Komunikasi. Bandung: PT Remaja Rosdakarya. Cet. Ke-7

Fattah, Nanang. (2000). Manajemen Berbasis Sekolah. Bandung: Andika.

Hasibuan, Melayu. (2007). Manajemen Dasar, Pengertian, Dan Masalah. Jakarta: Bumi Aksara.

I Made Angga Wiguna dan Dharma Suputra (2016). Pengaruh Tindakan Supervisi, Pengalaman Kerja, Komitmen Organisasi, dan Komitmen Profesional Terhadap Kepuasan Kerja Auditor. E-Jurnal Akuntansi Universitas Udayana. Vol.16.1. 
Lantip \& Sudiyono. (2011). Supervisi Subana, M. Dan Sudrajat. (2005). DasarPendidikan, Yogyakarta: Gava Media.

Mulyasa. E, (2012), Manajemen dan Dasar Penelitian Ilmiah. Bandung: CV Pustaka Pelajar.

Kepemimpinan Kepala Sekolah, Jakarta: Bumi Aksara.

Munir, Abdul. (2013). Menjadi Kepala Sekolah Efektif. Yogjakarta: Ar-Ruzz Media.

Purwanto, Ngalim. (1998). Administrasi dan Supervisi Pendidikan. Bandung: Remaja Rosdakarya.

Sahertian, A. Piet. (2000). Supervisi Pendidikan dalam Rangka Inservice Education. Jakarta: Rineka Cipta.

Samana, A. (1994). Profesionalisme Keguruan: Yogyakarta. Kanisius.

Siagian, Sondang P. (2006). Teori Dan Kepemimpinan. Jakarta: Rineka Cipta.

Suprihatiningrum, Jamil. (2013). Guru Profesional Pedoman Kinerja, Kualifikasi \& Kompetisi Guru. Yogyakarta: Arruz Media

Suranto, A.W. (2011). Komunikasi Interpersonal. Yogyakarta: Graha Ilmu, Ed. 1.

Sutrisno, Edy. (2011). Manajemen Sumber Daya Manusia. Jakarta: Kencana.

Virgana. (2014). Kepuasan Kerja Guru Matematika Ditinjau Dari Pengaruh Supervisi Kepala Sekolah dan Motivasi Kerja Guru. Jurnal Formatif. Vol 4 No 1. 